\title{
THE IMPACT OF GOVERNANCE EFFECTIVENESS AND COMPANY SIZE ON ENVIRONMENTAL PERFORMANCE
}

\author{
Irma Paramita Sofia \\ Pembangunan Jaya University \\ irma.paramita@upj.ac.id
}

\begin{abstract}
In making rational decisions, investors need a complete, accurate, and timely information. Companies can disclose information such as the implementation of good corporate governance, financial performance, and sustainability report. This research aims to obtain evidence that good corporate governance and corporate size have an effect on environment performance. We use sustainability reporting disclosure as a proxy for environmental achievement of the company. This study indicates that (1) good corporate governance has no effects on environmental performance; (2) corporate size has no effects on sustainability report disclosure.
\end{abstract}

Keywords: Good Corporate Governance, Sustainability Report Disclosure, Environmental Performance, Audit Committee.

\section{INTRODUCTION}

Today, competition in the business sector is increasing (Bukhori, 2017). This competition resulted in all companies issuing their power and effort to achieve maximum profit increases. The business is carried out, so that the company can maintain its survival (going concern). The effort was also carried out to increase company profits which later could increase investor interest in buying company shares.

But in times when environmental awareness is increasing, various parties related to the company's business increasingly demand transparency and accountability in activities related to the sustainability of the company (Adhipradana \& Daljono, 2014). In addition to increasing environmental awareness, the shift of view in the business world which previously focused solely on achieving profit or the level of profit of the company, stakeholders now demand that businesses also think about the planet (place or natural location where the company is located) (Aulia \& Syam, 2013). The concept that combines these three things is called the triple bottom line concept (Wijayanti, 2016).

In recent years, some companies in Indonesia have begun to balance between profit orientation and environmental improvement (Idah, 2013). Therefore, companies in addition to carrying out activities to earn profits or profits must also have a social responsibility to help solve social problems related to where the company is located (Khafid \& Mulyaningsih, 2015).

Environmental damage caused by the company's business activities tells us that there are still many companies that are developing in Indonesia that are less concerned about the losses that must be borne by the community as a result of their business activities (Aniktia \& 
Khafid, 2015). According to Koblun (2015), many cases of environmental damage occur in the world, companies that are not environmentally friendly have a business that will not last long because the company's image in the eyes of customers and society will be bad if there are cases related to environmental damage (Prahadi, 2015 ) Social and environmental issues circulating in the community make the company carry out various social activities and need to disclose them in sustainability reporting (Adhipradana \& Daljono, 2014).

Since the beginning of 2000, The Global Reporting Initiative (GRI) is trying to develop standards for sustainability reporting, namely GRI or G3 Sustainability Reporting Guidelines (Tumewu, 2017). Sustainability reporting is financial and non-financial reports published by the company through the information contained within the scope of the company and economic and social activities (Dewi \& Sudana, 2015).

The sustainability report is a medium for companies to not only report on financial aspects but to report non-financial aspects such as social and environment to stakeholders (Wijayanti, 2016). According to Darwin (2016), said that The sustainability report is very necessary so that stakeholders, including the community, know all forms of corporate responsibility to the community and the environment (Sari \& Marsono, 2013).

In order to minimize the negative impacts caused by business activities, the government issues regulations on corporate social and environmental responsibility. Therefore, when looking at the aims and objectives of the BUMN, it has become an obligation of SOEs to realize public benefits in the form of providing guidance and assistance to the community or can also be referred to as social responsibility of a BUMN (Lubis et al, 2017).
The existence of strict rules that require companies responsibilities, this encourages company managers to disclose sustainability report (Sari \& Marsono, 2013).

Companies with large sizes get more attention from the public and tend to reveal more extensive information as an effort to maintain the legitimacy of the company that can be realized through sustainability report disclosures (Sari \& Marsono, 2013). Companies with have large sizes should implement corporate management functions.

The company's concern for the environment is corporate social responsibility, which has recently been sharply highlighted by various interest groups in the community so that the company's image is at risk if the board of directors and board of commissioners do not pay close attention to this aspect (Daniri, 2014).

Research related to company size, corporate governance, financial performance, and sustainability report disclosure variables have been carried out by several previous researchers. (Khafid \& Mulyaningsih, 2015) found the influence of company size on sustainability report disclosures, whereas (Sari \& Marsono, 2013) found no influence in company size on disclosure of sustainability report.

Research by (Hasanah, Syam, \& Jati, 2015) revealed that corporate governance does not affect the disclosure of sustainabilityreport.Research(Setiawan,2 06 ) found that corporate governance has an effect on financial performance.

Based on the phenomenon and the existence of differences in the results of several previous studies as well as the interrelationship between the variables of company size, corporate governance, financial performance and disclosure of sustainability report, it makes it an interesting thing to study. The researcher took the company Non-Financial State- 
Owned Enterprises and mining sector companies on the Indonesia Stock Exchange as a population and sample in this study because of several phenomena that occurred related to environmental pollution carried out by state-owned companies and mining sector companies. As well as state-owned enterprises and mining sector companies should disclose social and environmental responsibility as stipulated in the Limited Liability Company Law and the Law on StateOwned Enterprises. Researchers also chose companies from Non-Financial State-Owned Enterprises and mining sector companies because researchers wanted to see the influence of sustainability report disclosures on companies whose company activities were related to natural resources. Researchers also want to see whether sustainability report disclosures can mediate between company size and corporate governance on financial performance.

\section{LITERATURE REVIEW}

\subsection{Stakeholder Theory}

Stakeholder theory extends organizational responsibility to all stakeholders not only to investors or owners (Donaldson \& Preston, 1995). Stakeholder theory is one of the main theories that are widely used to underlie research on sustainability report (Taringan \& Semuel, 2014).

\subsection{Legitimacy Theory}

The legitimacy theory concern on the interaction between the company and the community and is able to harmonize with the prevailing social normal where the company conducts its business activities (Muallifin \& Priyadi, 2016). If the organization provides social contributions, then the existence of the company and the activities carried out get "status" and "blessing". The company can disclose information relating to social organizations, community communities and the environment that can be expressed through sustainability reports as accountability to the public which aims to gain the legitimacy of the community and explain how the social and environmental impacts caused by the company (Muallifin \& Priyadi, 2016).

\subsection{Company Size}

The size of the company determines the number of members associated with the selection of ways to control activities in an effort to achieve its objectives (Torang, 2014). The size of the company also determines the level of investor confidence, requires good credibility so the company needs to contribute to social growth and the surrounding environment (Nasir, Ilham, \& North, 2014).

Corporate governance is one of the management mechanisms in the implementation of corporate governance which is expected to give trust to the agent (management) in managing owner's wealth (shareholders), and the owner becomes more convinced that theagentwillnotcommit fraud for the welfare of the agent, so as to minimize conflicts of interest and minimize agency costs (Tumewu, 2017).

\subsection{Sustainability Report}

Both stakeholders'theory and legitimacy are both theories that explain the motivation of managers to carry out sustainability reports (Wijayanti, 2016). A sustainability report is a new method that is widely used by companies to communicate the influence of companies on social, environmental and economic performance (Burhan \& Rahmanti, 2012). Likewise, according to (Sari \& Marsono, 2013) that sustainability reporting is a form of environmental and social responsibility 
reports that reveal the company's financial performance.

\subsection{Sustainability Report category}

The sustainability report disclosure will have dimensions of:

1) Economic dimensions

The economic dimension is divided into several aspects, namely economic performance, market presence, indirect economic impacts, and procurement practices.

2) Environmental dimensions

Environmental dimensions relate to the impact of organizations on living and nonliving natural systems. The environmental dimension is divided into several aspects, namely material, transportation, other aspects, supplier assessment of the environment, and complaints mechanism for environmental problems.

3) Social dimensions

Social dimension relates to the impact that the organization has on the social system in which the organization operates. The social dimension contains labor practices and the convenience of work, human rights, society and responsibility for products.

\section{Research Hypothesis}

Effect of Company Size on Sustainability Report Disclosures

The greater the size of a company, the wider the stakeholders (Khafid \& Mulyaningsih, 2015). Companies with large sizes get more attention from the public and tend to spend more on disclosing broader (Sari \& Marsono, 2013). Larger companies tend to disclose more information and allow the company to disclose the sustainability report (Idah, 2013). Therefore, researchers can draw hypotheses as follows:
$\mathrm{H}_{1}$ : The size of the company influences the Sustainability Report Disclosure.

\section{Corporate Governance of Sustainability Report Disclosures \\ Research conducted by (Sari \&} Marsono, 2013) and (Aniktia \& Khafid, 2015) that corporate governance with audit committee indicators has a positive effect on the disclosure of sustainability report. Furthermore, the research conducted by (Idah, 2013) and (Tumewu, 2017) revealed that corporate governance with the indicators of the board of directors had a positive effect on the disclosure of sustainability report. Therefore, researchers can draw hypotheses as follows:

$\mathrm{H}_{2}$ : Corporate governance has an effect on Sustainability Report Disclosures

\section{RESEARCH METHODS}

Research method contains a description of how the research will be carried out operationally. Therefore, this section contains research objectives, research variables, populations, and data analysis methods.

\subsection{Object of research}

The object of research is a scientific goal to obtain data with specific objectives and uses about an objective, valid, and reliable thing about something (certain variables) (Sugiyono, 2012). The object of this study is the influence of company size and corporate governance on sustainability report disclosure, as well as its implications for financial performance.

\subsection{Data collection}

The data used refers to information collected from existing sources, through intermediary media, namely through the official website of each company and 
the IDX website (www.idx.co.id). Data collection is done by searching and recording secondary data that has been obtained.

Sampling is done using the purposive sampling method. The purposive sampling method is a technique of determining samples with consideration or certain criteria (Sujarweni, 2016). The samples in this study are as follows:

1 Companies of Non-Financial StateOwned Enterprises and mining sector companies listed on the Indonesia Stock Exchange in 20132017.

2 Companies of Non-Financial StateOwned Enterprises and mining sector companies that publish annual reports and sustainability reports for 2012-2017 respectively.

\subsection{Data Processing}

The data collected in this study was obtained through descriptive statistical testing and linear regression analysis using EViews version 9.0. The first and second hypothesis is the test with multiple linear regression tests. Equation model used:

Which:

$$
\mathrm{Y}=\mathrm{a}+\mathrm{b}_{1} \mathrm{X}_{1}+\mathrm{b}_{2} \mathrm{X}_{2}+\mathrm{e}
$$

Y (Independent Variable): Sustainability Reporting

$\mathrm{a}=$ constants

$\mathrm{b}=$ regression coefficient

$\mathrm{X}_{1}$ : (Independent Variable 1): Company size variable

$\mathrm{X}_{2}$ : (Independent Variable2) :Corporate Governance variable

\section{RESULTS AND DISCUSSION}

\subsection{Descriptive Statistics}

In this study, company and corporate size act as independent variables, and disclosure of sustainability report act as the dependent variable. The results of the descriptive statistics of each variable are as follows:

Table 1: Results of Descriptive Statistics Analysis

Descriptive Statistics

\begin{tabular}{|c|c|c|c|c|c|}
\hline Variable & $\mathrm{N}$ & Min & Max & Mean & $\begin{array}{c}\text { Std. } \\
\text { Deviation }\end{array}$ \\
\hline SRDI & 50 & 26 & 98 & 51.7 & 17.383 \\
\hline TA & 50 & 3105 & 32150891 & 261903 & 103701 \\
\hline $\mathrm{CG}$ & 50 & 1518 & 21492191 & 170256 & 399042 \\
\hline $\begin{array}{l}\text { Valid N } \\
\text { (listwise) }\end{array}$ & 50 & & & & \\
\hline
\end{tabular}

(Source: Secondary Data Processed with SPSS, 2018)

The entire variable has a mean that is greater than std. deviation, thus indicating good results.

\subsection{Hypothesis testing Determination Coefficient Test ( $R$ Square)}

Test of the coefficient of determination (R Square) basically measures how far the ability of the model in explaining variations in independent variables. The deterrence coefficient value is between zero and one. A small $\mathrm{R}$ Square value shows the ability of independent variables to explain variations in the dependent variable is very limited (Ghozali I., 2013). The R Square will be changed in the form of a percentage which means the percentage of the influence of the independent variable on the dependent variable.

Table 2: Determination Coefficient Test Results

\begin{tabular}{|c|c|c|c|c|}
\hline \multicolumn{1}{|c|}{ Model Summary } \\
& & & Adjusted & $\begin{array}{c}\text { Std. Error } \\
\text { of the } \\
\text { Estimate }\end{array}$ \\
\hline 1 & $R$ & $R$ Square & $R$ Square & 17.53870 \\
\hline
\end{tabular}

a. Predictors: (Constant), $C G, T A$ 
Table 2 shows that the value of $R$ Square is 0.024 or 2.4 percent. The $\mathrm{R}$ Square number implies that company size and governance affect the sustainability report disclosure by 2.4 percent. The rest is influenced by other variables outside of this regression model.

\section{Partial Test (T Test)}

Partial test ( $t$ test) aims to determine the role of each independent variable, namely company size (LnTA) and corporate governance on environmental performance which is proxied by SRDI. Test criteria with the confidence level used is 95 percent or a significance level of 5 percent $(\alpha=0.05)$. That is, if the significant value produced by the $t$ test is $<0.05$, it can be concluded that the independent variable has a significant effect on the dependent variable partially.

Table 3. shows that the coefficient value ( $\beta 1)$ for Total Assets is $-2,014$ and the significance value is 0.412 The significance value obtained is greater than 0.05 so that it can be said statistically, H1 in this study was rejected. Similarly, the coefficient for the Governance variable is $-4,795$ and the significance value is 0.452 . Thus, it can be concluded that Governance does not significantly affect the disclosure of sustainability report.

\begin{tabular}{ccccccc}
\multicolumn{8}{c}{ Tabel 3 T Test Results } \\
COEFFICIENTS
\end{tabular}

\subsection{Discussion}

\section{Company Size for Sustainability Report Disclosures}

In this study, the variable size of the company is measured by calculating Ln Total Assets. Based on the tests that have been carried out, the results show that the Total Asset does not significantly affect the disclosure of sustainability report. The significance value obtained is greater than 0.005 (0.412> 0.005). Thus, H1 which states that the size of the company influences the Sustainability Report Disclosure is rejected. The results of this study are in line with the research conducted by (Sari \& Marsono, 2013).

The results of this study prove that the companies of Non-Financial StateOwned Enterprises and mining sector companies are companies that have a large company size but do not necessarily disclose the sustainability report because it is still voluntary. Jensen and Meckling (1976) argue that large companies will have the incentive to hold information that contains relevant values to avoid pressures of political costs in the law and tax increases, and pressure to carry out social responsibility. For these reasons, it is possible for management to prefer to disclose the report as needed. Thus, it can be said that the existence of companies of Non-Financial StateOwned Enterprises and mining sector companies do not necessarily disclose social, economic and environmental responsibilities in the sustainability report.

The Board of Directors and Audit Committee has the right to represent the company in matters outside and inside the company (Rachmawati, Rikumahu, \& Dillak, 2017). If the corporate environment is harmonious, the company's activities will run effectively and efficiently if the implementation of corporate corporate governance runs well and consistently. This harmony will 
be an important motivation and capital for the company in carrying out its activities and will make it easier for companies to achieve their goals and one of the company's goals is to get profit (Astuti \& Kusumadini, 2016). The results of this study cannot prove that the effectiveness of performance resulting from the number of board meetings can affect the increase in financial performance.

\section{Corporate Governance of Sustainability Report}

Disclosures in this study, corporate governance variables are measured by calculating the number of audit committee meetings and the board of directors over a period of one year. Based on the testing that has been done, the results obtained indicate that the audit committee has no effect on the Sustainability Report Disclosure significantly, while the board of directors has an effect on the Sustainability Report Disclosure significantly. The significance value obtained is greater than $0.005(0.452>$ 0.005). Thus, $\mathrm{H} 2$ which states that Governance (CG) affects the Disclosure of Sustainability Report rejected The results of this study are in line with the research conducted by (Idah, 2013) and (Nasir, Ilham, \& North, 2014). The frequency of audit committee meetings is getting more frequent, the supervision carried out will be better and the quality of disclosure of social information carried out is increasingly widespread (Sari \& Marsono, 2013). This is not comparable with the results of this study which proves that the frequency of meetings conducted by the audit committee has no role in disclosing the sustainability report. This result can be caused by meetings being held by the audit committee less effectively, where the audit committee members prioritize personal and group interests rather than the interests of the company. (Adhipradana \& Daljono, 2014).

\section{CONCLUSION}

This research was conducted to determine the effect of company size and governance on an environmental performance that is proxied by sustainability report. Based on the description and analysis that has been stated in the previous chapters, the following conclusions are obtained:

1. Company size does not affect the disclosure of sustainability report.

The results of this study are in line with the research conducted by (Sawitri, Wahyuni, \& Yuniarta, 2017) and (Arisadi, Djumahir, \& Djazuli, 2013).

The results of this study prove that the companies of Non-Financial State-Owned Enterprises and the mining sector have large total assets and can improve the company's financial performance. The relationship between company size occurs because large companies that have been listing in Indonesia get more profits from their operations, so that an increase in the size of the company can increase the profitability of the company (Arisadi, Djumahir, \& Djazuli, 2013).

2. Corporate governance has no effect on Sustainability Report disclosures. The results of this study are in line with the research conducted by (Ainurrofiq, 2016).

The audit committee is tasked with assisting and strengthening the functions of the board of commissioners in carrying out the supervisory function (Widyati, 2013). If supervision is done better and is expected to reduce management efforts to manipulate problems related to financial data and accounting procedures, so that the 
company's financial performance will increase (Rachmawati, Rikumahu, \& Dillak, 2017). This opinion is in line with the results of this study which proves that for non-financial stateowned enterprises and the mining sector, the number of meetings between audit committee members can increase

Based on the results of the research and discussion carried out, as well as the limitations of the research experienced by the authors, the suggestions that the authors can give in subsequent research are as follows:

1. For the next researcher, it is expected to be able to use other indicators besides the variables used in this study to measure the effect of independent variables on the dependent variable. In addition, further researchers are also expected to be able to expand data acquisition; not only limited to

\section{REFFERENCE}

Adhipradana, F., \& Daljono. (2014). Pengaruh Kinerja Keuangan, Ukuran Perusahaan, Dan Corporate Governance Terhadap Pengungkapan Sustainability Report. Diponegoro Journal of Accounting Volume 3 Nomor 1, 112.

Ainurrofiq, M. (2016). Pengaruh struktur modal dan good corporate governance terhadap kinerja keuangan. 1-12.

Aniktia, R., \& Khafid, M. (2015). Pengaruh Mekanisme Good Corporate Governance dan Kinerja Keuangan Terhladap Pengungkapan Sustainability Report. Accounting Analysis Journal 4(3), 3.
2. state-owned companies and the mining sector.

3. For investors and prospective investors, it is expected to choose a company that is not only good in its economic aspects, but also good in social and environmental aspects. This is because both aspects are needed to achieve the sustainability of a company.

4. For the Indonesian government, it is hoped that a new policy can be implemented in which all companies are required to carry out social and environmental responsibilities, so that all corporate sectors are more concerned with the social and environmental conditions of their companies.
Aulia, A. S., \& Syam, D. (2013). Pengaruh karakteristik perusahaan terhadap praktek pengungkapan sustainability reporting dalam laporan tahunan perusahaan publik di Indonesia. Jurnal Reviu Akuntansi dan Keuangan Vol. 3 No. 1, 403-414.

Arisadi, Y. C., Djumahir, \& Djazuli, A. (2013). Pengaruh Ukuran Perusahaan, Umur Perusahaan, Current Ratio, Debt to Equity Ratio dan Fixed Asset to Total Asset Ratio terhadap Kinerja Keuangan pada Perusahaan Manufaktur di Bursa Efek Indonesia. Jurnal Aplikasi Manajemen Volume 11 Nomor 4, 567-574.

Bukhori, M. R. (2017). Pengaruh pengungkapan sustainability report 
terhadap kinerja keuangan. Sistem informasi, Keuangan, Auditing, dan Perpajakan Vol. 2 No. 1, 35-48.

Burhan, A. H., \& Rahmanti, W. (2012). The Impact Of Sustainability Reporting On Company Performance. Journal of Economics, Business, and Accountancy Ventura Volume 15 No. 2, 257-272.

Daniri, M. A. (2014). Lead by GCG. Jakarta: Gagas Bisnis.

Dewi, K. E., \& Sudana, I. P. (2015). Sustainability reporting dan profitabilitas (studi pada pemenang indonesian sustainability reporting awards). E-Jurnal Akuntantasi Universitas Udayana 12.3, 624.

Donaldson, T., \& Preston, L. E. (1995). The Stakeholder Theory of the Corporation: Concepts, Evidence, and Implications. Academy of Management Review Vol. 20, No. 1, 65-91.

Freeman, R. E., \& Reed, D. L. (1983). Stockholders and Stakeholders: A New Perspective on Corporate Governance. Californian Management Review Vol. 25 No. 2, 88-106.

Hasanah, N., Syam, D., \& Jati, A. W. (2015). Pengaruh Corporate Governance terhadap Pengungkapan Sustainability Report pada Perusahaan di Indonesia. Jurnal Reviu Akuntansi dan Keuangan, 711-720.

Idah. (2013). Corporate governance dan karakteristik perusahaan dalam pengengkupan sustainability report. Accounting Analysis Journal 2 (3), 3015.

Isbanah, Y. (2015). Pengaruh ESOP, Leverage, dan Ukuran Perusahaan terhadap Kinerja Keuanfan Perusahaan di Bursa Efek Indonesia. Journal of Research in Economics and Management Volume 15 No. 1, 28-41.
Jensen, M., \& Meckling, W. H. (1976). Theory of the Firm : Managerial Behaviour, Agency Costs and Ownership Structure. Journal of Financial Economics, Vol. 3.

Khafid, M., \& Mulyaningsih. (2015). Kontribusi karakteristik perusahaan dan corporate governance terhadap publikasi sustainability. Ekuitas: Jurnal ekonomi dan Keuangan Volume 19 Nomor 3, 341.

Lubis , D. F., Nasution, B., Sunarmi, \& Siregar, M. (2017). Implementasi Pasal 74 Undang-Undang No. 40 Tahun 2007 Tentang Perseroan Terbatas Mengenai Tanggung Jawab Sosial Perusahaan Di Ptpn III. USU Law Journal, Vol.5, No.2, 158-181.

Muallifin, O. R., \& Priyadi, M. P. (2016). Dampak Pengungkapan Sustainability Report terhadap kinerja keuangan dan kinerja pasar. Jurnal Ilmu dan Riset Akuntansi: Volume 5 Nomor 5, 1-20.

Nasir, A., Ilham, E., \& Utara, V. I. (2014). Pengaruh karakteristik perusahaan dan corporate governance terhadap pengungkapan sustainability report pada perusahaan LQ45 yang terdaftar. Jurnal Ekonomi Volume 22 Nomor 1,1-18.

Pikiran Rakyat. (2017, Desember 21). Pemprov Jabar Apresiasi Industri Taati Aturan Lingkungan Hidup. Retrieved from Pikiran Rakyat: http://www.pikiranrakyat.com/jawabarat/2017/12/21/pemprov-jabarapresiasi-industri-taati-aturanlingkungan-hidup-416356

Pujiastuti. (2015). Pengaruh Karakteristik Perusahaan dan Good Corporate Governance terhadap Luas Pengungkapan Sustainability Report. Jurnal Studi Manajemen dan Bisnis Vol. 2 No. 1, 12-23.

Sari, M. P., \& Marsono. (2013). Pengaruh kinerja keuangan, ukuran 
perusahaan, dan corporate governance terhadap pengungkapan sustainability report. Diponegoro Journal of Accounting Volume 2 Nomor 3, 2.

Sawitri, N. M., Wahyuni, M. A., \& Yuniarta, G. A. (2017). Pengaruh Kinerja Keuangan, Ukuran Perusahaan Dan Struktur Kepemilikan Terhadap Profitabilitas . e-Journal Nama Jurnal Universitas Pendidikan Ganesha Volume 7 No. 1, 1-12.

Sekaran, U., \& Bougie, R. (2017). Metode Penelitian untuk Bisnis Edisi 6 Buku 1. Jakarta: Salemba Empat.

Setiawan, A. (2016). Pengaruh corporate governance terhadap kinerja keuangan perusahaan. Jurnal SIKAP Vol. 1 No.1 , 1-8.

Solomon, J. (2013). Corporate Governance and Accountability . United Kingdom: John Wiley \& Sons Ltd.

Sugiyono. (2012). Metode Penelitian: Kuantitatif, Kualitatif, dan $R \& D$. Bandung: Penerbit Alfabeta.

Sujarweni, V. W. (2016). Kupas Tuntas Penelitian Akuntansi dengan SPSS. Yogyakarta: Pustaka Baru Press.

Taringan, J., \& Semuel, H. (2014). Penungkapan Sustainabilty report dan kinerja keuangan. Jurnal Akuntansi dan Keuangan Vol.16 No. 2, 88-101.

Torang, S. (2014). Organisasi \& Manajemen: Perilaku, Struktur, Budaya \& Perubahan Organisasi. Bandung: Penerbit Alfabeta.

Tumewu, J. (2017). Pengaruh karakteristik perudahaan dan corporate governance terhadap praktik publikasi sustainability report pada perusahaan publik di Indonesia. Jurnal Ilmiah Akuntansi Fakultas Ekonomi Volume 3 No. 1, 1-19.

Undang-undang Perseroan Terbatas No 40 tahun 2007 . (n.d.).
Wijayanti, R. (2016). Pengaruh Pengungkapan Sustainability Report terhadap Kinerja Keuangan Perusahan. Syariah Paper Accounting FEB UMS, 39-51.

Widyati, M. F. (2013). Pengaruh Dewan Direksi, Komisaris Independen, Komite Audit, Kepemilikan Manajerial Dan Kepemilikan Institusional Terhadap Kinerja Keuangan. Jurnal Ilmu Manajemen Volume 1 Nomor 1, 234-249.

Rachmawati, I. A., Rikumahu, B., \& Dillak, V. J. (2017). Pengaruh Dewan Direksi, Dewan Komisaris, Komite Audit Dan Corporate Social Responsibility Terhadap Kinerja Keuangan Perusahaan. Jurnal Akuntansi \& Ekonomi Fe. Un Pgri Kediri Vol. 2 No. 2, 54-70. 